\title{
DETERMINASI KINERJA PENGELOLAAN PENDAPATAN ASLI DAERAH
}

\author{
Ssurtikanti, Surtikanti ${ }^{1}$; Nanang Suryana ${ }^{2}$ \\ ${ }^{1}$ Universitas Komputer Indonesia; ${ }^{2}$ Telkom University Bandung \\ surtikanti@email,unikom.ac.id ${ }^{1}$; nanangsuryana@ telkomuniversity.ac.id ${ }^{2}$
}

\begin{abstract}
ABSTRAK
The objective of this research is identify the effect of job motivation and controling to official of region taxation performance of sukabumi regencies. According to the objective, this research are explanatory research, is done by using survey method. The research was conducted by using method to population of 104 Apparatus at Official of Region Taxation Performance Of Sukabumi Regencies. The samples were taken in the amount of 83 Apparatus based on Slovin method. According to the analysis of the results of data processing the results are that job motivation and controling simultaneously and individually have significantly influence on official of region taxation performance of sukabumi regencies.
\end{abstract}

\section{Keyword: Job motivation, contoling and region taxation performance}

\section{PENDAHULUAN}

\section{A. Latar Belakang Masalah}

Salah satu indikator keberhasilan pelaksanaan kebijakan desentralisasi dan otonomi daerah sebagaimana diatur dalam UndangUndang Nomor 32 Tahun 2004 tentang Pemerintahan Daerah adalah besaran kontribusi penerimaan Pendapatan Asli Daerah terhadap pemenuhan kebutuhan pembiayaan daerah sebagaimana tersusun dalam Anggaran Pendapatan dan Belanja Daerah (APBD). Pemahaman konsep keberhasilan ini tentu tidak terbatas hanya pada pemikiran tentang kemampuan daerah dalam mengelola sumber-sumber penerimaan PAD, tetapi mencakup pemikiran yang lebih luas lagi, yaitu bahwa daerah mampu meningkatkan dan memperluas pembangunan sektor- sektor perekonomian yang menjadi sumber-sumber penerimaan PAD.

Dalam konteks itu, semakin besar kontribusi penerimaan PAD terhadap APBD maka semakin kecil ketergantungan daerah pada kebijakan anggaran pemerintah; dan sebaliknya, semakin kecil kontribusi penerimaan PAD terhadap APBD maka semakin besar ketergantungan daerah pada kebijakan anggaran pemerintah. Bila pembiayaan suatu daerah terlalu bergantung pada kebijakan anggaran pemerintah, maka dapat dipastikan bahwa daerah tersebut tidak mampu mengefektifkan pelaksanaan kebijakan desentralisasi dan otonomi daerah. Akibat dari ketidakmampuan daerah dalam melaksanakan kebijakan desentralisasi dan otonomi daerah antara lain lamban dan terbatasnya kinerja pembangunan untuk 
meningkatkan

kesejahteraan

masyarakat.

Dalam perspektif pemikiran yang demikian itu, kontribusi penerimaan PAD terhadap APBD Kabupaten Sukabumi, Provinsi Jawa Barat tampak masih jauh dari yang diharapkan. Sebagai misal, pada tahun anggaran 2004 kontribusi PAD terhadap APBD Kabupaten Sukabumi hanya mencapai Rp.36.234.497.000,- atau 7,97 persen dari total penerimaan APBD sebesar Rp.454.531.272.000,-Kemudian pada tahun anggaran 2005 kontribusi PAD terhadap penerimaan APBD Kabupaten Sukabumi hanya mencapai Rp. 42.379.458.000,- atau 8,65 persen dari total penerimaan APBD sebesar Rp. 489.807.605.000,-

Ketidakmampuan Pemda Kabupaten Sukabumi dalam meningkatkan kontribusi penerimaan PAD terhadap kebutuhan pembiayaan daerah dapat dianggap sebagai suatu fenomena kinerja pengelolaan sumber-sumber penerimaan PAD. Atau dengan anggapan lain, kinerja pengelolaan PAD pada Dinas Pendapatan Daerah Kabupaten Sukabumi masih belum optimal. Fenomena tersebut jelas tidak berdiri sendiri. Diyakini terdapat sejumlah faktor yang mempengaruhi kinerja pengelolaan PAD yang dilaksanakan atau dikoordinasikan oleh Dinas Pendapatan Daerah Kabupaten Sukabumi.

\section{B. Rumusan Masalah}

Berdasarkan fenomena yang telah diuraikan pada latar belakang penelitian, maka masalah dalam penelitian ini dirumuskan sebagai berikut :
1. Bagaiman pengaruh Motivasi Kerja terhadap Kinerja Pengelolaan PAD pada Dinas Pendapatan Daerah Kabupaten Sukabumi.

2. Bagaiman pengaruh Pengawasan Melekat terhadap Kinerja Pengelolaan PAD pada Dinas Pendapatan Daerah Kabupaten Sukabumi.

3. Bagaimana pengaruh Motivasi Kerja dan Pengawasan Melekat secara bersama-sama terhadap Kinerja Pengelolaan PAD pada Dinas Pendapatan Daerah Kabupaten Sukabumi.

\section{KAJIAN PUSTAKA, KERANGKA PEMIKIRAN DAN HIPOTESIS}

\section{A. Motivasi Kerja}

Motivasi adalah suatu kebutuhan atau dorongan di dalam diri individu yang menggerakkan individu untuk melakukan tindakan untuk mencapai tujuan tertentu. Menurut Malthis (2006:114), motivasi adalah keinginan dalam diri seseorang yang menyebabkan orang tersebut bertindak. Biasanya orang bertindak karena suatu alasan untuk mencapai tujuan. Memahami motivasi sangatlah penting karena kinerja, reaksi terhadap kompensasi dan persoalan sumber daya manusia yang lain dipengaruhi dan mempengaruhi motivasi.

Menurut Manullang (2005:146) motivasi atau motivation berarti pemberian motif, penimbulan motive, atau hal yang menimbulkan dorongan atau keadaan yang menimbulkan dorongan. Motivasi dapat pula diartikan faktor yang 
mendorong orang untuk bertindak dengan cara tertentu.

Dapat ditarik suatu kesimpulan bahwa motivasi adalah keinginan dalam diri seseorang untuk melakukan suatu tindakan, yang merupakan suatu proses dimana perilaku diberikan energi dan diarahkan untuk mencapai tujuan dan harapan yang ia inginkan.

\section{B. Pengawasan Melekat}

Pengertian pengawasan ialah proses pengamatan dari pelaksanaan yang sedang dilakukan dapat berjalan sesuai dengan rencana yang telah ditentukan (Siagian, 2006:31). Pengawasan bertujuan agar ketentuan-ketentuan dalam pekerjaan yang telah ditentukan benar-benar ditaati serta dilaksanakan secara baik, sehingga mencapai tujuan yang telah direncanakan secara efektif dan efesien (Depkeu, 2004:15). Pengawasan adalah suatu proses untuk menetapkan pekerjaan apa yang sudah dilaksanakan, menilainya dan mengoreksi bila perlu dengan maksud supaya pelaksanaan pekerjaan sesuai dengan rencana semula (Manullang, 2005:173). Definisi tersebut menekankan adanya mekanisme penilaian atas suatu kegiatan yang telah dilaksanakan

$$
\text { Berdasarkan deskripsi }
$$

pengertian yang tersaji diperoleh suatu konsep pemahaman bahwa pengawasan (controlling) dapat dianggap sebagai aktivitas untuk menemukan, mengoreksi penyimpangan penting dalam hasil yang dicapai dari aktivitas yang direncanakan. Pengawasan bertujuan untuk mencegah sedini mungkin terjadinya penyimpangan, pemborosan, penyelewengan, hambatan, kesalahan dan kegagalan dalam pencapaian tujuan dan sasaran serta pelaksanaan tugas-tugas organisasi. Tujuan pelaksanaan pengawasan juga dapat diartikan sebagai suatu pendekatan manajerial untuk meningkatkan efisiensi, efektivitas, rasionalitas dan ketertiban dalam pencapaian tujuan dan pelaksanaan tugas organisasi.

Sejalan dengan pengertian pengawasan yang telah diuraikan diatas, maka dapatlah dikemukan bahwa fungsi pengawasan tersebut tidak hanya dilaksanakan pada saat pekerjaan itu berlangsung, tetapi juga dilaksanakan sebelum pekerjaan dilakukan (pengawsan prefentif) maupun pada waktu pekerjaan telah selesai (pengawasan refresif), dengan maksud agar dimungkinkan dibuat rencana yang lebih baik dan pelaksanaan pekerjaan yang lebih sempurna.

Proses pengawasan itu terdiri dari suatu proses yang dibentuk oleh tiga macam langkah yang bersifat universal, yaitu 1. Mengukur hasil pekerjaan; 2. Membandingkan hasil pekerjaan dengan standar dan memastikan perbedaan (apabila ada perbedaan); dan 3. Mengoreksi penyimpangan yang tidak dikehendaki melalui tindakan perbaikan. (Winardi, 1983: 381)

\section{Kinerja Pengelolaan Pendapatan Asli Daerah}

Kecenderungan perilaku aparatur pemerintah dalam melaksanakan fungsinya, banyak ditentukan oleh sikap mental yang memberikan pemahaman kepadanya mengenai yang seharusnya dilakukan. Setiap aparatur diharapkan mampu memberikan kontribusi bagi kemajuan organisasi seperti menghasilkan sesuatu yang 
memiliki nilai secara cepat, tepat dengan biaya yang terjangkau (ekonomis). Aktualisasi kegiatan pegawai tersebut terwujud dalam kinerja.

Dalam kaitannya dengan organisasi, kinerja organisasi merupakan gambaran dari kinerja para pegawainya. Hal ini sebagaimana dikemukakan Prawirosentono (1999:3), bahwa "bila kinerja karyawan baik maka kemungkinan besar kinerja perusahaan juga baik," atau sebaliknya Gibson (1988:13) "kinerja individu adalah dasar kinerja organisasi". Kinerja pegawai ini tidak terlepas dari adanya lingkungan kerja yang kondusif seperti, kondisi tempat kerja, peralatan kerja, dan fasilitas lainnya serta adanya sistem pemberian insentif, pemilihan dan penempatan pegawai, desain tugas dan pemberian pendidikan dan pelatihan akan memberikan dampak pada sikap dan perilaku aparatur dan dapat mendorong motivasi pegawai untuk berprestasi yang diperlihatkan melalui kinerjanya.

Dapat disimpulkan bahwa pada dasarnya kinerja merupakan suatu prestasi yang dicapai seseorang dalam melaksanakan tugas-tugas atau pekerjaannya sesuai dengan standar baku atau kinerja yang ditetapkan untuk melaksanakan tugas-tugas tersebut. Dalam konteks ini, kinerja pengelolaan Pendapatan Asli Daerah merupakan proses dan hasil kerja yang dicapai oleh seluruh unsur pimpinan dan staf Dinas Perndpatan Daerah Kabupaten Sukabumi dalam mengelola sumbersumber penerimaan PAD yaitu Pajak Daerah, Retribusi Daerah, Bagi Hasil Usaha Milik Daerah, dan Lain-lain PAD yang sah.
Penerimaan Pendapatan Asli Daerah merupakan salah satu indikator keberhasilan Daerah dalam melaksanakan desentralisasi dan otonomi daerah. Artinya, semakin besar kontribusi PAD terhadap APBD, maka semakin besar pula kemampuan daerah dalam mengelola sumber-sumber penerimaan PAD. Sumber-sumber pendapatan asli Daerah terdiri hasil pajak daerah, hasil retribusi daerah, hasil pengelolaan kekayaan Daerah yang dipisahkan, dan lain-lain pendapatan asli Daerah yang sah. (Pasal 157 UU No.32/2004) Dari pernyataan pasal ini dapat diketahui bahwa sumbersumber penerimaan PAD penerimaan Pajak Daerah, penerimaan Retribusi Daerah, penerimaan dari pengelolaan kekayaan Daerah dan penerimaan dari Lain-lain PAD yang sah.

\section{Kerangka Pemikiran}

Pengaruh Motivasi Kerja Terhadap Kinerja Pengelolaan Pendapatan Asli Daerah

Hasil penelitian Olivia Theodora (2015) menjelaskan bahwa motivasi relatedness menjadi motivasi yang paling dominan pengaruhnya terhadap kinerja karyawan. Hal ini sama dengan hasil penelitian Slamet Riyadi (2011) menyatakan motivasi kerja berpengaruh signifikan terhadap kinerja karyawan.

Pengaruh Pengawasan Melekat Terhadap Kinerja Pengelolaan Pendapatan Asli Daerah

\section{Hipotesis}

Berdasarkan kerangka pemikiran yang demikian itu, Hipotesis yang diuji dalam penelitian 
ini diajukan dengan pernyataan sebagai berikut :

1. Terdapat pengaruh Motivasi Kerja terhadap Kinerja Pengelolaan PAD pada Dinas Pendapatan Daerah Kabupaten Sukabumi.

2. Terdapat pengaruh Pengawasan Melekat terhadap Kinerja Pengelolaan PAD pada Dinas Pendapatan Daerah Kabupaten Sukabumi.

3. Terdapat pengaruh Motivasi Kerja dan Pengawasan Melekat secara bersamasama terhadap Kinerja Pengelolaan PAD pada Dinas Pendapatan Daerah Kabupaten Sukabumi.

\section{METODE PENELITIAN}

Penelitian ini menggunakan pendekatan kuantitatif dan sebagai pendukung argumen digunakan pendekatan kualitatif. Desain penelitian yang digunakan adalah analitik korelasional dengan metode survey khususnya menyangkut deskripsi potensi pajak serta dilengkapi dengan berbagai informasi dari aparat pemungut pajak pada Dinas Pendapatan Daerah Kabupaten Sukabumi.

Populasi yang menjadi obyek penelitian adalah keseluruhan pegawai sebanyak 148 pegawai unsur staf pada Dinas Pendapatan
Daerah Kabupaten Sukabumi. Untuk menentukan sampel penelitian adalah prosedur penarikan sampel berdasarkan strata (Stratified Proportional Random Sampling). Dengan total populasi 148 pegawai maka jumlah sampel diperoleh 108 sampel.

\section{HASIL PENELITIAN DAN PEMBAHASAN}

\section{A. Hasil Penelitian}

Data hasil tanggapan responden yang menjawab instrumen penelitian dengan skor 5 dan skor 4 dijadikan sebagai indikator baik tidaknya kinerja instrumen yang bersangkutan. Motivasi Kerja

Motivasi kerja pegawai di Dinas Pendapatan Daerah Kabupaten Sukabumi diukur melalui dua belas instrumen penelitian (butir pernyataan).

\section{a. Dimensi Kebutuhan Ekonomi}

Hasil survey yang dilakukan oleh peneliti pada pegawai di Dinas Pendapatan Daerah Kabupaten Sukabumi menunjukkan bahwa kebutuhan ekonomi para pegawai termasuk tinggi. Hal ini tercermin dari akumulasi tanggapan responden terhadap empat butir pertanyaan pada dimensi kebutuhan ekonomi, dimana sebanyak 21,08\% responden menjawab sangat tinggi(skor 5) dan sebanyak $43,98 \%$ responden menjawab tinggi(skor 4 
Tabel 4.1

Tanggapan Responden Mengenai Kebutuhan Ekonomi

\begin{tabular}{|c|c|c|c|c|c|c|c|}
\hline Butir Pernyataan & & Skor 5 & $\begin{array}{c}\text { Skor } \\
4\end{array}$ & Skor 3 & Skor 2 & Skor 1 & $\square$ \\
\hline Besarnya insentif yang diterima jelas & $\mathrm{F}$ & 48 & 30 & 5 & 0 & 0 & 83 \\
\hline $\begin{array}{l}\text { insentif atau tambahan penghasilan itu } \\
\text { penting bagi saya }\end{array}$ & $\%$ & 57.83 & 36.14 & 6.02 & 0.00 & 0.00 & 100 \\
\hline Manfaat insentif yang diterima cukup & $\mathrm{F}$ & 4 & 36 & 38 & 5 & 0 & 83 \\
\hline $\begin{array}{l}\text { besar bagi keperluan ekonomi saya, } \\
\text { karena untuk memenuhi kebutuhan hidup } \\
\text { yang semakin mahal saya tidak bisa } \\
\text { mengandalkan gaji pokok saja }\end{array}$ & $\%$ & 4.82 & 43.37 & 45.78 & 6.02 & 0.00 & 100 \\
\hline Insentif yang diharapkan oleh saya adalah & $\mathrm{F}$ & 3 & 24 & 50 & 6 & 0 & 83 \\
\hline $\begin{array}{l}\text { bahwa insentif itu bisa meringankan } \\
\text { beban biaya hidup keluarga yang semakin } \\
\text { berat }\end{array}$ & $\%$ & 3.61 & 28.92 & 60.24 & 7.23 & 0.00 & 100 \\
\hline Cara Mendapatkan insentif seharusnya & $\mathrm{F}$ & 15 & 56 & 9 & 2 & 1 & 83 \\
\hline $\begin{array}{l}\text { sesuai dengan ketentuan dan norma kerja } \\
\text { yang berlaku, namun bila perlu saya pun } \\
\text { tak ragu melakukan cara-cara lain untuk } \\
\text { mendapat insentif yang lebih banyak }\end{array}$ & $\%$ & 18.07 & 67.47 & 10.84 & 2.41 & 1.20 & 100 \\
\hline \multirow{2}{*}{$\begin{array}{c}\text { Akumulasi Empat Pertanyaan Pada } \\
\text { Dimensi Kebutuhan Ekonomi }\end{array}$} & $\mathrm{F}$ & 70 & 146 & 102 & 13 & 1 & 332 \\
\hline & $\%$ & 21.08 & 43.98 & 30.72 & 3.92 & 0.30 & 100 \\
\hline
\end{tabular}

Sumber: Hasil data kuesioner

\section{b. Dimensi Kebutuhan Sosial}

Hasil survey yang dilakukan oleh peneliti pada pegawai di Dinas Pendapatan Daerah Kabupaten Sukabumi menunjukkan bahwa kebutuhan sosial para pegawai termasuk tinggi. Hal ini tercermin dari akumulasi tanggapan responden terhadap empat butir pertanyaan pada dimensi kebutuhan sosial, dimana sebanyak $20,18 \%$ responden menjawab sangat tinggi(skor 5) dan sebanyak 48,19\% responden menjawab tinggi(skor 4 ).

Tabel 4.2

Tanggapan Responden Mengenai Kebutuhan Sosial

\begin{tabular}{|l|c|c|c|c|c|c|c|}
\hline \multicolumn{1}{|c|}{ Butir Pernyataan } & & Skor 5 & $\begin{array}{c}\text { Skor } \\
\mathbf{4}\end{array}$ & Skor 3 & Skor 2 & Skor 1 & $\square$ \\
\hline $\begin{array}{l}\text { Saya merasa agak sulit mendapat } \\
\text { perhatian atau penghargaan sosial dari } \\
\text { pimpinan karena pimpinan di tempat saya } \\
\text { bekerja kurang memperhatikan staf. }\end{array}$ & F & 2 & 42 & 31 & 7 & 1 & 83 \\
\hline $\begin{array}{l}\text { Saya memang mendapat perhatian dari } \\
\text { Sa }\end{array}$ & F & 2.41 & 50.60 & 37.35 & 8.43 & 1.20 & 100 \\
\hline
\end{tabular}




\begin{tabular}{|c|c|c|c|c|c|c|c|}
\hline Butir Pernyataan & & Skor 5 & $\begin{array}{c}\text { Skor } \\
4\end{array}$ & Skor 3 & Skor 2 & Skor 1 & $\square$ \\
\hline $\begin{array}{l}\text { rekan sekerja, namun perhatian tersebut } \\
\text { lebih banyak di luar urusan pekerjaan } \\
\text { saya }\end{array}$ & $\%$ & 14.46 & 56.63 & 25.30 & 3.61 & 0.00 & 100 \\
\hline $\begin{array}{l}\text { Saya memang merasa perlu mendapat } \\
\text { perhatian dari unit kerja terkait untuk } \\
\text { mengkoordinasikan pekerjaan, namun } \\
\text { perhatian tersebut masih kurang } \\
\text { maksimal }\end{array}$ & $\mathrm{F}$ & 46.99 & 28.92 & 20.48 & 2.41 & 1.20 & 83 \\
\hline $\begin{array}{l}\text { Perhatian dari lingkungan kerja itu } \\
\text { menurut saya penting sekali, agar setiap } \\
\text { pegawai merasa dirinya dihargai, tapi } \\
\text { kenyataannya tidak sedikit pegawai yang } \\
\text { cenderung tidak peduli terhadap } \\
\text { lingkungan kerjanya }\end{array}$ & $\begin{array}{l}\mathrm{F} \\
\%\end{array}$ & $\begin{array}{c}14 \\
16.87\end{array}$ & \begin{tabular}{|c|}
47 \\
56.63
\end{tabular} & $\begin{array}{c}18 \\
21.69\end{array}$ & $\begin{array}{c}4 \\
4.82\end{array}$ & $\begin{array}{c}0 \\
0.00\end{array}$ & \begin{tabular}{|c|}
83 \\
100
\end{tabular} \\
\hline \multirow{2}{*}{$\begin{array}{c}\text { Akumulasi Empat Pertanyaan Pada } \\
\text { Dimensi Kebutuhan Sosial }\end{array}$} & $\mathrm{F}$ & 67 & 160 & 87 & 16 & 2 & 332 \\
\hline & $\%$ & 20.18 & 48.19 & 26.20 & 4.82 & 0.60 & 100 \\
\hline
\end{tabular}

Sumber: Hasil data kuesioner

\section{c. Dimensi Kebutuhan Kerja}

Hasil survey yang dilakukan oleh peneliti pada pegawai di Dinas Pendapatan Daerah Kabupaten Sukabumi menunjukkan bahwa kebutuhan kerja para pegawai termasuk cukup tinggi. Hal ini tercermin dari akumulasi tanggapan responden terhadap empat butir pertanyaan pada dimensi kebutuhan kerja, dimana sebanyak $18,07 \%$ responden menjawab sangat tinggi (skor 5) dan sebanyak 37,95\% responden menjawab tinggi (skor 4).

Tabel 4.3

Tanggapan Responden Mengenai Kebutuhan Kerja

\begin{tabular}{|c|c|c|c|c|c|c|c|}
\hline Butir Pernyataan & & Skor 5 & \begin{tabular}{|c} 
Skor \\
4 \\
\end{tabular} & Skor 3 & Skor 2 & $\begin{array}{c}\text { Skor } \\
1 \\
\end{array}$ & $\square$ \\
\hline Setiap pegawai, termasuk saya, pasti & $\mathrm{F}$ & 37 & 23 & 19 & 3 & 1 & 83 \\
\hline $\begin{array}{l}\text { membutuhkan ruang kerja yang nyaman, } \\
\text { karena ruangan kerja saya, juga ruang } \\
\text { kerja teman-teman saya kurang nyaman }\end{array}$ & $\%$ & 44.58 & 27.71 & 22.89 & 3.61 & 1.20 & 100 \\
\hline Saya membutuhkan perlengkapan & $\mathrm{F}$ & 4 & 21 & 51 & 5 & 2 & 83 \\
\hline $\begin{array}{l}\text { administrasi seperti antara lain filling } \\
\text { cabinet, telepon dan facsimile, tapi } \\
\text { sayang penyediaan peralatan tersebut di } \\
\text { tempat saya sangat tidak memadai }\end{array}$ & $\%$ & 4.82 & 25.30 & 61.45 & 6.02 & 2.41 & 100 \\
\hline Saya juga membuuhkan perlengkapan & $\mathrm{F}$ & 0 & 37 & 43 & 3 & 0 & 83 \\
\hline
\end{tabular}


Determinasi Kinerja Pengelolaan Pendapatan Asli Daerah (Ssurtikanti, Surtikanti; Nanang Suryana)

\begin{tabular}{|c|c|c|c|c|c|c|c|}
\hline Butir Pernyataan & & Skor 5 & $\begin{array}{c}\text { Skor } \\
4\end{array}$ & Skor ? & Skor 2 & $\begin{array}{c}\text { Skor } \\
1\end{array}$ & $\square$ \\
\hline $\begin{array}{l}\text { teknis pekerjaan seperti satu set } \\
\text { komputerisasi, perlengkapan } \\
\text { tersebut tidak bisa saya dapat }\end{array}$ & $\%$ & 0.00 & 44.58 & 51.81 & 3.61 & 0.00 & 100 \\
\hline $\begin{array}{l}\text { Saya memerlukan perlengkapan } \\
\text { pelaporan seperti antara lain data } \\
\text { kegiatan namun data tersebut kurang } \\
\text { tersedia dan tidak lengkap }\end{array}$ & $\begin{array}{l}\mathrm{F} \\
\%\end{array}$ & 22.89 & 54.22 & 19.28 & 3.61 & 0.00 & 83 \\
\hline $\begin{array}{c}\text { Akumulasi Empat Pertanyaan Pada } \\
\text { Dimensi Kebutuhan Kerja }\end{array}$ & $\begin{array}{l}\mathrm{F} \\
\% \\
\end{array}$ & \begin{tabular}{|c|}
60 \\
18.07 \\
\end{tabular} & $\begin{array}{c}126 \\
37.95 \\
\end{array}$ & \begin{tabular}{|c|}
129 \\
38.86 \\
\end{tabular} & $\begin{array}{c}14 \\
4.22 \\
\end{array}$ & $\begin{array}{c}3 \\
0.90 \\
\end{array}$ & $\begin{array}{l}332 \\
100\end{array}$ \\
\hline
\end{tabular}

Sumber: Hasil data Kuesioner

Setelah diuraikan gambaran tanggapan responden mengenai motivasi kerja pegawai pada masingmasing dimensi, selanjutnya diuraikan gambaran tanggapan responden mengenai motivasi kerja pegawai secara keseluruhan dengan cara mengakumulasikan tanggapan responden dari masing-masing dimensi dan hasilnya seperti yang dijabarkan pada gambar berikut.

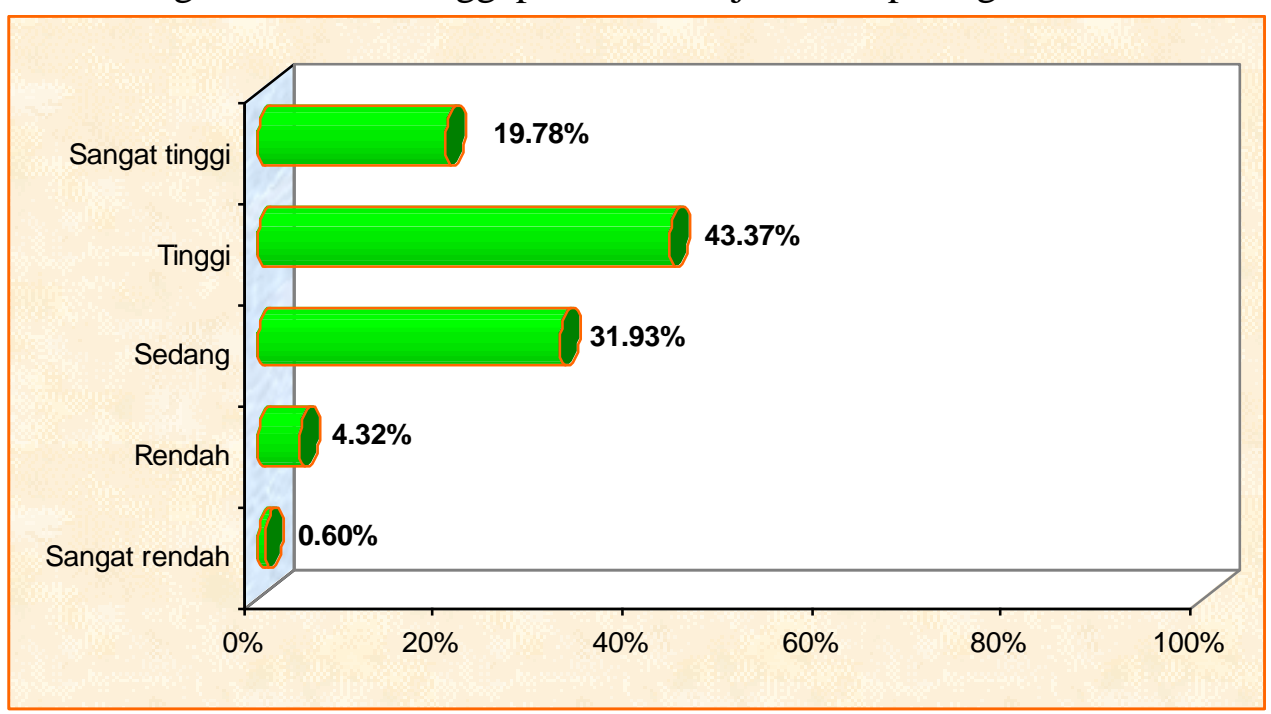

Sumber: Tabel $4.1 \mathrm{~s} / \mathrm{d}$ Tabel 4.3

Gambar 4.1. Diagram Distribusi Tanggapan Responden Tentang Motivasi Kerja Pegawai di Dinas Pendapatan Daerah Kabupaten Sukabumi

Dari gambaran data seperti yang ada pada gambar 4.1 menunjukkan bahwa motivasi kerja pegawai di Dinas Pendapatan Daerah Kabupaten Sukabumi dapat dikatakan sudah tinggi. Hal ini tercermin dari hasil tanggapan responden yang sebagian besar memberikan penilaian positif (Sangat tinggi + Tinggi $=63.15 \%$ ) atas 
motivasi kerja pegawai di Dinas Pendapatan Daerah Kabupaten Sukabumi dan sebanyak $31.93 \%$ menilai sedang.

\section{Pengawasan Melekat}

Pengawasan melekat di Dinas

Pendapatan Daerah Kabupaten

Sukabumi diukur melalui tiga belas instrumen penelitian (butir pernyataan).

\section{a. Dimensi Pemantauan}

Hasil survey yang dilakukan oleh peneliti pada pegawai di Dinas Pendapatan Daerah Kabupaten Sukabumi menunjukkan bahwa pemantauan yang dilakukan terhadap para pegawai termasuk tinggi. Hal ini tercermin dari akumulasi tanggapan responden terhadap empat butir pertanyaan pada dimensi pemantauan, dimana sebanyak $50,30 \%$ responden menjawab sangat tinggi(skor 5) dan sebanyak $36,75 \%$ responden menjawab tinggi(skor 4 ).

Tabel 4.4

Tanggapan Responden Mengenai Pemantauan

\begin{tabular}{|c|c|c|c|c|c|c|c|}
\hline Butir Pernyataan & & Skor 5 & $\begin{array}{c}\text { Skor } \\
4\end{array}$ & Skor 3 & Skor 2 & Skor 1 & $\square$ \\
\hline Pelaksanaan pemantauan yang dilakukan & $\mathrm{F}$ & 38 & 32 & 13 & 0 & 0 & 83 \\
\hline $\begin{array}{l}\text { pimpinan terhadap pelaksanaan ketentuan } \\
\text { kerja masih lemah dan oleh sebab itu } \\
\text { tidak sedikit pekerjaan yang } \\
\text { penyelesaiannya kurang sesuai dengan } \\
\text { ketentuan kerja yang berlaku }\end{array}$ & $\%$ & 45.78 & 38.55 & 15.66 & 0.00 & 0.00 & 100 \\
\hline Pelaksanaan pemantauan yang dilakukan & $\mathrm{F}$ & 43 & 24 & 15 & 1 & 0 & 83 \\
\hline $\begin{array}{l}\text { pimpinan terhadap pelaksanaan prosedur } \\
\text { kerja juga lemah, dan oleh sebab itu tidak } \\
\text { sedikit pekerjaan yang penyelesaiannya } \\
\text { kurang sesuai dengan prosedur kerja yang } \\
\text { harus ditempuh }\end{array}$ & $\%$ & 51.81 & 28.92 & 18.07 & 1.20 & 0.00 & 100 \\
\hline \multirow{2}{*}{$\begin{array}{l}\text { Karena lemahnya pengawasan melekat } \\
\text { yang dilakukan pimpinan, maka proses } \\
\text { kerja menjadi kurang efektif }\end{array}$} & $\mathrm{F}$ & 24 & 48 & 10 & 0 & 1 & 83 \\
\hline & $\%$ & 28.92 & 57.83 & 12.05 & 0.00 & 1.20 & 100 \\
\hline \multirow{2}{*}{\begin{tabular}{|llr} 
Karena lemahnya pengawasan & melekat \\
yang dilakukan pimpinan, & maka \\
pentingnya koordinasi kerja & kurang \\
diperhatikan oleh staf & & \\
\end{tabular}} & $\mathrm{F}$ & 62 & 18 & 3 & 0 & 0 & 83 \\
\hline & $\%$ & 74.70 & 21.69 & 3.61 & 0.00 & 0.00 & 100 \\
\hline \multirow{2}{*}{$\begin{array}{c}\text { Akumulasi Empat Pertanyaan Pada } \\
\text { Dimensi Pemantauan }\end{array}$} & $F$ & 167 & 122 & 41 & 1 & 1 & 332 \\
\hline & $\%$ & 50.30 & 36.75 & 12.35 & 0.30 & 0.30 & 100 \\
\hline
\end{tabular}

Sumber: Hasil Data Kuesioner 


\section{b. Dimensi Pemeriksaan}

Hasil survey yang dilakukan oleh peneliti pada pegawai di Dinas Pendapatan Daerah Kabupaten Sukabumi menunjukkan bahwa pemeriksaan yang dilakukan terhadap para pegawai termasuk baik. Hal ini tercermin dari akumulasi tanggapan responden terhadap empat butir pertanyaan pada dimensi pemeriksaan, dimana sebanyak $46,69 \%$ responden menjawab sangat baik(skor 5) dan sebanyak $34,64 \%$ responden menjawab baik(skor 4).

Tabel 4.5

Tanggapan Responden Mengenai Pemeriksaan

\begin{tabular}{|c|c|c|c|c|c|c|c|}
\hline Butir Pernyataan & & Skor 5 & \begin{tabular}{|c|} 
Skor \\
4
\end{tabular} & Skor 3 & Skor 2 & Skor 1 & $\square$ \\
\hline \multirow{2}{*}{$\begin{array}{l}\text { Pimpinan kurang ketat dalam melakukan } \\
\text { pemeriksaan terhadap penggunaan } \\
\text { anggaran pekerjaan, karena itu tidak } \\
\text { sedikit terjadi penyimpangan dalam } \\
\text { penggunaan anggaran kinerja } \\
\end{array}$} & $\mathrm{F}$ & 12 & 30 & 40 & 1 & 0 & 83 \\
\hline & $\%$ & 14.46 & 36.14 & 48.19 & 1.20 & 0.00 & 100 \\
\hline \multirow{2}{*}{$\begin{array}{l}\text { Pimpinan kurang berani melakukan } \\
\text { peneguran apabila terjadi penggunaan } \\
\text { fasilitas pekerjaan yang sesuai dengan } \\
\text { ketentuan kerja yang berlaku }\end{array}$} & $\mathrm{F}$ & 42 & 37 & 2 & 2 & 0 & 83 \\
\hline & $\%$ & 50.60 & 44.58 & 2.41 & 2.41 & 0.00 & 100 \\
\hline \multirow{2}{*}{$\begin{array}{l}\text { Pimpinan kurang pandai dalam } \\
\text { mengarahkan teknis pekerjaan yang } \\
\text { dilakukan staf dan oleh sebab itu tidak } \\
\text { sedikit pekerjaan yang kurang efekif } \\
\text { penyelesaiannya }\end{array}$} & $\mathrm{F}$ & 64 & 17 & 2 & 0 & 0 & 83 \\
\hline & $\%$ & 77.11 & 20.48 & 2.41 & 0.00 & 0.00 & 100 \\
\hline \multirow{2}{*}{$\begin{array}{l}\text { Pimpinan kurang pandai dan kurang kritis } \\
\text { dalam memantau hasil pekerjaan karena } \\
\text { itu tidak sedikit hasil kegiatan yang } \\
\text { kurang sesuai dengan perencanaan }\end{array}$} & $\mathrm{F}$ & 37 & 31 & 12 & 3 & 0 & 83 \\
\hline & $\%$ & 44.58 & 37.35 & 14.46 & 3.61 & 0.00 & 100 \\
\hline \multirow{2}{*}{$\begin{array}{c}\text { Akumulasi Empat Pertanyaan Pada } \\
\text { Dimensi Pemeiksaan }\end{array}$} & $\mathrm{F}$ & 155 & 115 & 56 & 6 & $\mathbf{0}$ & 332 \\
\hline & $\%$ & 46.69 & 34.64 & 16.87 & 1.81 & 0.00 & 100 \\
\hline
\end{tabular}

Sumber: Hasil Data Kuesioner

\section{c. Dimensi Penilaian}

Hasil survey yang dilakukan oleh peneliti pada pegawai di Dinas Pendapatan Daerah Kabupaten Sukabumi menunjukkan bahwa penilaian yang dilakukan pimpinan terhadap para pegawai termasuk baik. Hal ini tercermin dari akumulasi tanggapan responden terhadap lima butir pertanyaan pada dimensi penilaian, dimana sebanyak $37,83 \%$ responden menjawab sangat baik(skor 5) dan sebanyak 35,18\% responden menjawab baik(skor 4). 
Tabel 4.6 Tanggapan Responden Mengenai Penilaian

\begin{tabular}{|c|c|c|c|c|c|c|c|}
\hline Butir Pernyataan & & Skor 5 & $\begin{array}{c}\text { Skor } \\
4\end{array}$ & Skor 3 & Skor 2 & Skor 1 & $\square$ \\
\hline \multirow{2}{*}{$\begin{array}{l}\text { Pimpinan kurang pandai dan tidak kritis } \\
\text { dalam menilai produktivitas kerja staf }\end{array}$} & $\mathrm{F}$ & 2 & 18 & 53 & 8 & 2 & 83 \\
\hline & $\%$ & 2.41 & 21.69 & 63.86 & 9.64 & 2.41 & 100 \\
\hline \multirow{2}{*}{$\begin{array}{l}\text { Pimpinan juga kurang pandai dalam } \\
\text { menilai efektivitas kerja staf, terutama } \\
\text { efektifitas kerja kolektif }\end{array}$} & $\mathrm{F}$ & 18 & 39 & 19 & 7 & 0 & 83 \\
\hline & $\%$ & 21.69 & 46.99 & 22.89 & 8.43 & 0.00 & 100 \\
\hline \multirow{2}{*}{$\begin{array}{l}\text { Pimpinan kurang memperhatikan } \\
\text { pentingnya efisiensi kerja dan kurang } \\
\text { pandai dalam menilai efisiensi kerja staf, } \\
\text { terutama dalam hal penggunaan anggaran } \\
\text { kinerja }\end{array}$} & $F$ & 56 & 19 & 7 & 1 & 0 & 83 \\
\hline & $\%$ & 67.47 & 22.89 & 8.43 & 1.20 & 0.00 & 100 \\
\hline \multirow{2}{*}{$\begin{array}{l}\text { Pimpinan kurang memperhatikan } \\
\text { pentingnya efisiensi kerja dan kurang } \\
\text { pandai dalam menilai efisiensi kerja staf, } \\
\text { terutama dalam hal penggunaan anggaran } \\
\text { kinerja }\end{array}$} & $F$ & 36 & 39 & 7 & 1 & 0 & 83 \\
\hline & $\%$ & 43.37 & 46.99 & 8.43 & 1.20 & 0.00 & 100 \\
\hline \multirow{2}{*}{$\begin{array}{l}\text { Pimpinan kurang menunjukkan kapasitas } \\
\text { kerja yang maksimal dalam } \\
\text { melaksanakan fungsi pengaawasan } \\
\text { melekat }\end{array}$} & $\mathrm{F}$ & 45 & 31 & 7 & 0 & 0 & 83 \\
\hline & $\%$ & 54.22 & 37.35 & 8.43 & 0.00 & 0.00 & 100 \\
\hline \multirow{2}{*}{$\begin{array}{c}\text { Akumulasi Lima Pertanyaan Pada } \\
\text { Dimensi Penilaian }\end{array}$} & $\mathrm{F}$ & 157 & 146 & 93 & 17 & 2 & 415 \\
\hline & $\%$ & $\mathbf{3 7 . 8 3}$ & 35.18 & 22.41 & 4.10 & 0.48 & 100 \\
\hline
\end{tabular}

Sumber: Hasil Data Kuesioner $\begin{array}{lcc}\text { Setelah } & \text { diuraikan } & \text { gambaran } \\ \text { tanggapan } & \text { responden } & \text { mengenai }\end{array}$ pengawasan melekat pada masingmasing dimensi, selanjutnya diuraikan gambaran tanggapan responden mengenai pengawasan melekat secara keseluruhan dengan cara mengakumulasikan tanggapan responden dari masing-masing dimensi dan hasilnya seperti yang dijabarkan pada gambar berikut.

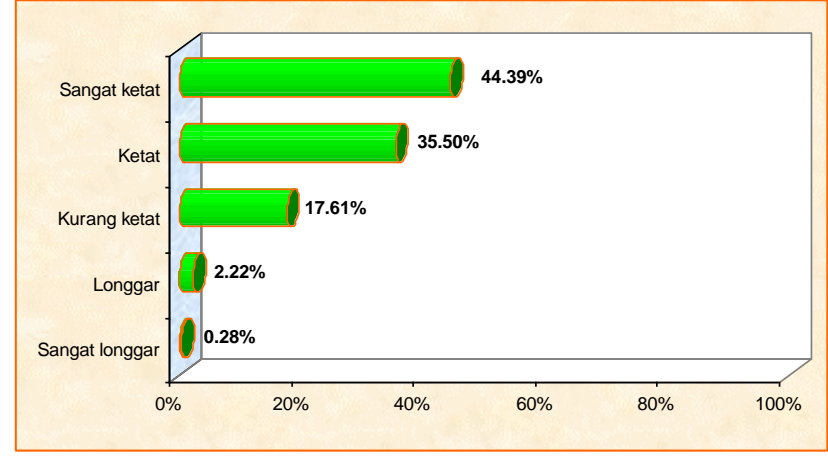

Sumber: Tabel 4.4 s/d Tabel 4.6 
Gambar 4.2 Diagram Distribusi Tanggapan Responden Tentang Pengawasan Melekat di Dinas Pendapatan Daerah Kabupaten Sukabumi

Dari gambaran data seperti yang ada pada gambar 4.2 menunjukkan bahwa pengawasan melekat yang dilakukan pimpinan terhadap pegawai di Dinas Pendapatan Daerah Kabupaten Sukabumi dapat dikatakan ketat. Hal ini tercermin dari hasil tanggapan

responden yang sebagian besar memberikan penilaian positif (Sangat ketat + Ketat $=79.89 \%)$ atas pengawasan yang dilakukan pimpinan terhadap pegawai di Dinas Pendapatan Daerah Kabupaten Sukabumi.

Tabel 4.7 Tanggapan Responden Mengenai Kualitas Pelayanan instrumen penelitian (butir pernyataan).

\section{a. Dimensi Kualitas Pelayanan}

Hasil survey yang dilakukan oleh peneliti pada pegawai di Dinas Pendapatan Daerah Kabupaten Sukabumi menunjukkan bahwa kualitas pelayanan yang diberikan di Dinas Pendapatan Daerah Kabupaten Sukabumi sudah memuaskan memuaskan. Hal ini tercermin dari akumulasi tanggapan responden terhadap tiga butir pertanyaan pada

dimensi kualitas pelayanan, dimana sebanyak $29,72 \%$ responden menjawab sangat memuaskan (skor 5) dan sebanyak $42,57 \%$ responden menjawab memuaskan (skor 4).

\begin{tabular}{|c|c|c|c|c|c|c|c|}
\hline Butir Pernyataan & & Skor 5 & $\begin{array}{c}\text { Skor } \\
4\end{array}$ & Skor 3 & Skor 2 & Skor 1 & $\square$ \\
\hline \multirow{2}{*}{$\begin{array}{l}\text { Apakah fasilitas yang digunakan untuk } \\
\text { melakukan pelayanan pajak memadai }\end{array}$} & $F$ & 20 & 47 & 14 & 2 & 0 & 83 \\
\hline & $\%$ & 24.10 & 56.63 & 16.87 & 2.41 & 0.00 & 100 \\
\hline \multirow{2}{*}{$\begin{array}{l}\text { Apakah jumlah petugas pajak sekarang } \\
\text { ini memadai }\end{array}$} & $\mathrm{F}$ & 52 & 24 & 7 & 0 & 0 & 83 \\
\hline & $\%$ & 62.65 & 28.92 & 8.43 & 0.00 & 0.00 & 100 \\
\hline \multirow{2}{*}{$\begin{array}{l}\text { Bagaimanakah tingkat pemahaman dan } \\
\text { pengetahuan petugas tentan masalah } \\
\text { pajak }\end{array}$} & $\mathrm{F}$ & 2 & 35 & 39 & 5 & 2 & 83 \\
\hline & $\%$ & 2.41 & 42.17 & 46.99 & 6.02 & 2.41 & 100 \\
\hline \multirow{2}{*}{$\begin{array}{l}\text { Akumulasi Tiga Pertanyaan Pada } \\
\text { Dimensi Kualitas Pelayanan }\end{array}$} & $F$ & 74 & 106 & 60 & 7 & 2 & 249 \\
\hline & $\%$ & 29.72 & 42.57 & 24.10 & 2.81 & 0.80 & 100 \\
\hline
\end{tabular}

Sumber: Hasil Data Kuesioner

\section{Kinerja Pengelolaan Keuangan Daerah \\ Kinerja \\ pengelolaan \\ keuangan daerah di Dinas \\ Pendapatan Daerah Kabupaten \\ Sukabumi diukur melalui sebelas}

\section{b. Dimensi Responsivitas}

Hasil survey yang dilakukan oleh peneliti pada pegawai di Dinas Pendapatan Daerah Kabupaten Sukabumi menunjukkan bahwa responsivitas pegawai di Dinas 
Pendapatan Daerah Kabupaten Sukabumi sudah tinggi. Hal ini tercermin dari akumulasi tanggapan responden terhadap tiga butir pertanyaan pada dimensi responsivitas, dimana sebanyak $50,20 \%$ responden menjawab sangat tinggi (skor 5) dan sebanyak 39,76\% responden menjawab tinggi (skor 4 ).

Tabel 4.8

Tanggapan Responden Mengenai Responsivitas

\begin{tabular}{|c|c|c|c|c|c|c|c|}
\hline Butir Pernyataan & & Skor 5 & $\begin{array}{c}\text { Skor } \\
4 \\
\end{array}$ & Skor 3 & Skor 2 & Skor 1 & $\square$ \\
\hline \multirow{2}{*}{$\begin{array}{l}\text { Bagaimanakah keselarasan antara } \\
\text { program dengan keadaan dan kebutuhan } \\
\text { wajib pajak }\end{array}$} & $\mathrm{F}$ & 30 & 52 & 1 & 0 & 0 & 83 \\
\hline & $\%$ & 36.14 & 62.65 & 1.20 & 0.00 & 0.00 & 100 \\
\hline \multirow{2}{*}{$\begin{array}{l}\text { Bagaiamankah keselarasan antara } \\
\text { program dan kegiatan yang dilakukan }\end{array}$} & $\mathrm{F}$ & 57 & 21 & 5 & 0 & 0 & 83 \\
\hline & $\%$ & 68.67 & 25.30 & 6.02 & 0.00 & 0.00 & 100 \\
\hline \multirow{2}{*}{$\begin{array}{l}\text { Bagaimanakah kesempatan petugas } \\
\text { dalam mengembangkan program secara } \\
\text { operasional dilapangan }\end{array}$} & $\mathrm{F}$ & 38 & 26 & 19 & 0 & 0 & 83 \\
\hline & $\%$ & 45.78 & 31.33 & 22.89 & 0.00 & 0.00 & 100 \\
\hline \multirow{2}{*}{$\begin{array}{c}\text { Akumulasi Tiga Pertanyaan Pada } \\
\text { Dimensi Responsivitas }\end{array}$} & $\mathrm{F}$ & 125 & 99 & 25 & $\mathbf{0}$ & $\mathbf{0}$ & 249 \\
\hline & $\%$ & 50.20 & 39.76 & 10.04 & 0.00 & 0.00 & 100 \\
\hline
\end{tabular}

Sumber: Hasil Data Kuesioner

\section{c. Dimensi Responsibilitas}

Hasil survey yang dilakukan oleh peneliti pada pegawai di Dinas Pendapatan Daerah Kabupaten Sukabumi menunjukkan bahwa responsibilitas pegawai di Dinas Pendapatan Daerah Kabupaten Sukabumi sudah cukup tinggi. Hal ini tercermin dari akumulasi tanggapan responden terhadap dua butir pertanyaan pada dimensi responsibilitas, dimana sebanyak $34,34 \%$ responden menjawab tinggi (skor 4) dan sebanyak $48,80 \%$ responden menjawab cukup tinggi (skor 3).

Tabel 4.9

Tanggapan Responden Mengenai Responsibilitas

\begin{tabular}{|c|c|c|c|c|c|c|c|}
\hline Butir Pernyataan & & Skor 5 & \begin{tabular}{|c} 
Skor \\
4 \\
\end{tabular} & Skor 3 & Skor 2 & Skor 1 & $\square$ \\
\hline \multirow{2}{*}{$\begin{array}{l}\text { Apakah petugas administrasi mampu } \\
\text { menyusun administrasi keuangan pajak } \\
\text { secara benar }\end{array}$} & $\mathrm{F}$ & 1 & 18 & 58 & 6 & 0 & 83 \\
\hline & $\%$ & 1.20 & 21.69 & 69.88 & 7.23 & 0.00 & 100 \\
\hline \multirow{2}{*}{$\begin{array}{l}\text { Apakah Dinas Pengelolaan Pajak Daerah } \\
\text { mampu membuat kebijakan organisasi } \\
\text { dalam pembagian pekerjaan secara } \\
\text { terencana dan terkoordinir }\end{array}$} & $\mathrm{F}$ & 20 & 39 & 23 & 1 & 0 & 83 \\
\hline & $\%$ & 24.10 & 46.99 & 27.71 & 1.20 & 0.00 & 100 \\
\hline \multirow{2}{*}{$\begin{array}{c}\text { Akumulasi Tiga Pertanyaan Pada } \\
\text { Dimensi Responsibilitas }\end{array}$} & $\mathrm{F}$ & 21 & 57 & 81 & 7 & $\mathbf{0}$ & 166 \\
\hline & $\%$ & 12.65 & 34.34 & 48.80 & 4.22 & 0.00 & 100 \\
\hline
\end{tabular}


Sumber: Hasil Data Kuesioner

\section{d. Dimensi Akuntabilitas}

Hasil survey yang dilakukan oleh peneliti pada pegawai di Dinas Pendapatan Daerah Kabupaten Sukabumi menunjukkan bahwa akuntabilitas Dinas Pendapatan Daerah Kabupaten Sukabumi sudah tinggi. Hal ini tercermin dari akumulasi tanggapan responden terhadap tiga butir pertanyaan pada dimensi akuntabilitas, dimana sebanyak $51,41 \%$ responden menjawab sangat tinggi (skor 5) dan sebanyak $38,55 \%$ responden menjawab tinggi (skor 4).

Tabel 4.10

Tanggapan Responden Mengenai Akuntabilitas

\begin{tabular}{|c|c|c|c|c|c|c|c|}
\hline Butir Pernyataan & & Skor 5 & \begin{tabular}{|c} 
Skor \\
4 \\
\end{tabular} & Skor 3 & Skor 2 & Skor 1 & $\square$ \\
\hline \multirow{2}{*}{$\begin{array}{l}\text { Bagaimana kemampuan pimpinan dinas } \\
\text { dalam mengelola organisasinya untuk } \\
\text { mencapai tujuan }\end{array}$} & $\mathrm{F}$ & 55 & 21 & 6 & 0 & 1 & 83 \\
\hline & $\%$ & 66.27 & 25.30 & 7.23 & 0.00 & 1.20 & 100 \\
\hline \multirow{2}{*}{$\begin{array}{l}\text { Bagaimanakah kesesuaian antara } \\
\text { program yang disusun dengan norma dan } \\
\text { budaya masyarakat }\end{array}$} & $\mathrm{F}$ & 33 & 42 & 7 & 0 & 1 & 83 \\
\hline & $\%$ & 39.76 & 50.60 & 8.43 & 0.00 & 1.20 & 100 \\
\hline \multirow{2}{*}{$\begin{array}{l}\text { Apakah pemungut pajak telah sesuai } \\
\text { dengan aturan yang berlaku }\end{array}$} & $\mathrm{F}$ & 40 & 33 & 9 & 0 & 1 & 83 \\
\hline & $\%$ & 48.19 & 39.76 & 10.84 & 0.00 & 1.20 & 100 \\
\hline \multirow{2}{*}{$\begin{array}{c}\text { Akumulasi Tiga Pertanyaan Pada } \\
\text { Dimensi Akuntabilitas }\end{array}$} & $\mathrm{F}$ & 128 & 96 & 22 & $\mathbf{0}$ & 3 & 249 \\
\hline & $\%$ & 51.41 & 38.55 & 8.84 & 0.00 & 1.20 & 100 \\
\hline
\end{tabular}

Sumber: Hasil Data Kuesioner

Setelah diuraikan gambaran tanggapan responden mengenai kinerja pengelolaan pajak daerah pada masing-masing dimensi, selanjutnya diuraikan gambaran tanggapan responden mengenai kinerja pengelolaan pajak daerah secara keseluruhan dengan cara mengakumulasikan tanggapan responden dari masing-masing dimensi dan hasilnya seperti yang dijabarkan pada gambar berikut. 
Responsive, Volume 3 No. 2 Agustus 2020 : 117 - 134

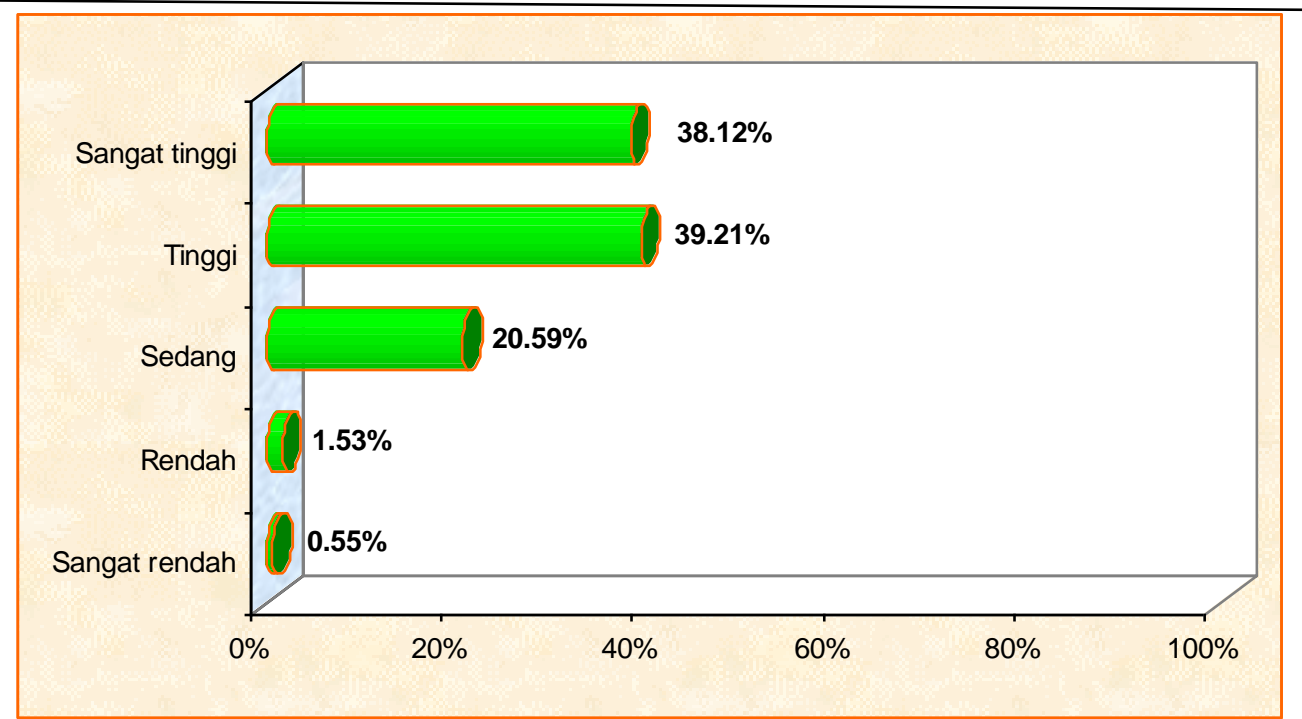

Sumber: Tabel $4.7 \mathrm{~s} / \mathrm{d}$ Tabel 4.10

Gambar 4.3 Diagram Distribusi Tanggapan Responden Tentang Kinerja Pengelolaan Pajak Daerah di Dinas Pendapatan Daerah Kabupaten Sukabumi

Dari gambaran data seperti yang ada pada gambar 4.3 menunjukkan bahwa kinerja pengelolaan pajak daerah di Dinas Pendapatan Daerah Kabupaten Sukabumi dapat dikatakan tinggi. Hal ini tercermin dari hasil tanggapan responden yang sebagian besar memberikan penilaian positif $($ Sangat tinggi + Tinggi $=77.33 \%)$ atas kinerja pengelolaan pajak daerah di Dinas Pendapatan Daerah Kabupaten Sukabumi.

\section{B. Pembahasan}

\section{a. Pengaruh Motivasi Kerja Terhadap Kinerja Pengelolaan Pajak Daerah}

Hasil pengujian hipotesis menunjukkan bahwa Ho ditolak dan $\mathrm{Ha}$ diterima sehingga dapat disimpulkan bahwa motivasi kerja memiliki pengaruh yang signifikan terhadap kinerja pengelolaan pajak daerah di Dinas Pendapatan Daerah
Kabupaten Sukabumi. Motivasi kerja berpengaruh positif terhadap kinerja pengelolaan pajak daerah di Dinas Pendapatan Daerah Kabupaten Sukabumi, artinya pegawai yang motivasi kerjanya tinggi.pada umumnya cenderung memiliki kinerja yang lebih tinggi dalam pengelolaan pajak daerah. Hal ini mendukung teori Newstrom dan Davis (1997) dalam Riniwati (2011:50), yang menjelaskan peran motivasi dan kemampuan pada kinerja (kinerja) yang tinggi dan didukung pula akan keragaman yang diberikan berupa produktivitas yang lebih baik.

Hasil penelitian ini konsisten dengan penelitian Arida (2010), Wulan (2011) dan Kusuma (2012) yang menyatakan bahwa lingkungan kerja berpengaruh terhadap kinerja karyawan. Karyawan yang memiliki motivasi kerja yang tinggi maka mereka akan memiliki dorongan 
untuk mau menggunakan seluruh kemampuannya untuk bekerja.

\section{b. Pengaruh Pengawasan Melekat Terhadap Kinerja Pengelolaan Pajak Daerah}

Hasil pengujian hipotesis menunjukkan bahwa Ho ditolak dan $\mathrm{Ha}$ diterima sehingga dapat disimpulkan bahwa pengawasan melekat secara parsial memiliki pengaruh yang signifikan terhadap kinerja pengelolaan pajak daerah di Dinas Pendapatan Daerah Kabupaten Sukabumi. Pengawasan melekat berpengaruh positif terhadap kinerja pengelolaan pajak daerah di Dinas Pendapatan Daerah Kabupaten Sukabumi, artinya pegawai yang diawasi pimpinan secara ketat pada umumnya cenderung memiliki kinerja yang lebih tinggi dalam pengelolaan pajak daerah.

\section{c. Pengaruh Motivasi Kerja, Pengawasan Melekat Terhadap Kinerja Pengelolaan Pajak Daerah}

Hasil penelitian diperoleh informasi bahwa $72,00 \%$ kinerja pengelolaan pajak daerah dapat dijelaskan oleh variabel motivasi kerja, pengawasan melekat secara bersama-sama, sementara sisanya sebesar 28,00\% dijelaskan oleh faktor/variabel lain .

Hasil pengujian hipotesis menunjukkan bahwa $\mathrm{H}_{0}$ ditolak dan Ha diterima, jadi dapat disimpulkan bahwa secara bersama-sama (simultan) motivasi kerja dan pengawasan melekat berpengaruh signifikan terhadap kinerja pengelolaan pajak daerah di Dinas Pendapatan Daerah Kabupaten Sukabumi.

\section{Kesimpulan}

Dari hasil penelitian dapat disimpulkan sebagai berikut :

1. Motivasi kerja secara parsial memiliki pengaruh yang signifikan terhadap kinerja pengelolaan pajak daerah di Dinas Pendapatan Daerah Kabupaten Sukabumi. Motivasi kerja berpengaruh positif terhadap kinerja pengelolaan pajak daerah di Dinas Pendapatan Daerah Kabupaten Sukabumi, artinya pegawai yang motivasi kerjanya tinggi.pada umumnya cenderung memiliki kinerja yang lebih tinggi dalam pengelolaan pajak daerah.

2. Pengawasan melekat secara parsial memiliki pengaruh yang signifikan terhadap kinerja pengelolaan pajak daerah di Dinas Pendapatan Daerah Kabupaten Sukabumi. Pengawasan melekat berpengaruh positif terhadap kinerja pengelolaan pajak daerah di Dinas Pendapatan Daerah Kabupaten Sukabumi, artinya pegawai yang diawasi pimpinan secara ketat .pada umumnya cenderung memiliki kinerja yang lebih tinggi dalam pengelolaan pajak daerah.

3. Pengaruh Motivasi Kerja dan Pengawasan Melekat Secara Simultan Terhadap Kinerja Pengelolaan Pajak Daerah 
Buku

DAFTAR PUSTAKA

Cynthia Novita Hidayat. 2015. Pengaruh Lingkungan Kerja Dan Motivasi Kerja Terhadap Kinerja Karyawan Kantor PT. Keramik Diamond Industries. AGORA Vol. 3, No. 2.

Devas, Binder, Booth, Davey, Kelly, 1999, Keuangan Pemerintah Daerah Indonesia, UI Press.

Gibson, Ivancevich. 1984. Organisasi dan Manajemen Perilaku Struktur Proses. Jakarta: Penerbit Erlangga.

Gordon, J.R, 1993, A Diagnostic Approach To Organizational Behavior, Boston : Allyn and Bacon.

Kusmanto, Sunarso. 2017. Pengaruh Pengawasan Melekat, Motivasi, Dan Pembagian Kerja Terhadap Kinerja Pegawai PD BPR BKK. Surakarta. Jurnal Manajemen Sumberdaya Manusia Vol. 3 No. 2 Desember 2007

Lembaga Administrasi Negara Republik Indonesia. 1997. Sistim Administrasi Negara Republik Indonesia-Jilid I \& II, Jakarta : PT.Toko Gunung Agung.

M . Manullang. 1993, Pengantar Teori Ekonomi Moneter, Medan : Bappit.

Nawawi, Hadari, 1994, Pengawasan Melekat di Lingkungan Aparatur Pemerintah, Jakarta : Erlangga. ,1998, Manajemen Sumber Daya Manusia : Untuk Bisnis Yang Kompetitif, Yogyakarta : Gajah Mada University Press.
Salindeho, John. 1995, Pengawasan Melekat Aspek-Aspek Terkait dan Implementasinya. Jakarta: Bumi Aksara.

Slamet Riyadi. 2011. Pengaruh Kompensasi Finansial, Gaya Kepemimpinan, dan Motivasi Kerja Terhadap Kinerja Karyawan pada Perusahaan Manufaktur di Jawa Timur, Surabaya. Jurnal Manajemen Dan Kewirausahaan, Vol.13, No. 1, MARET 2011:

Sujamto, 1992, Otonomi Birokrasi Partisipasi, Semarang : Dahara Prize.

Suparmoko, M. 2000. Keuangan Negara Dalam Teori dan Praktek. Yogyakarta: BPFE UGM.

$\begin{array}{cr}\text { Pembangunan, } & 1995 . \\ \text { : BPFE. } & \text { Ekonomi } \\ \text { Yogyakarta }\end{array}$

Supranto, J. 1987. Statistik-Teori dan Aplikasi, Jakarta : Erlangga. , 1997. Pengukuran Tingkat Kepuasan Pelanggan Untuk Menaikkan Pangsa Pasar, Jakarta : PT. Rineka Cipta.

Sumitro, Rohmat. 1990. Azas dan Dasar Perpajakan. Bandung: PT Eresco. 1994. Dasar Teori Ekonomi Pertumbuhan Dan Ekonomi Pembangunan. Jakarta: LP3ES

Terry, George R, 1977, Asas-Asas Manajemen (Principle of Management), Bandung : Penerbit ALUMNI.

Thoha, Miftah, 1996, Perilaku Organisasi-Konsep Dasar dan Aplikasinya, Jakarta : PT. Raja Grafindo. 
Wexley, Kenneth N dan Gary A. Yulk, 1992, Perilaku Organisasi Dan Psikologis Personalia, Jakarta : PT. Rineka Cipta.

Aldo Herlambang Gardjito Mochammad Al Musadieq Gunawan Eko Nurtjahjono (2014). Pengaruh Motivasi Kerja Dan Lingkungan Kerja Terhadap Kinerja Karyawan (Studi pada Karyawan Bagian Produksi PT. Karmand Mitra Andalan Surabaya) Jurnal Administrasi Bisnis (JAB) Vol. 13 No. 1 Agustus 2014 administrasibisnis.studentjournal .ub.ac.id

\section{Dokumen}

Undang-Undang Nomor 34 Tahun 2000, Tentang Perubahan Atas Undang-Undang Nomor 18 Tahun 1997 Tentang Pajak Daerah dan Retribusi Daerah. 